\title{
Construction and use of a prokaryotic expression system for Helicobacter pylori AhpC
}

Khalid Mehmood ${ }^{1,2,3^{*}}$ and Fariha Hasan ${ }^{1}$

\begin{abstract}
Background: Helicobacter pylori is an important pathogen responsible for human gastric problems like inflammation, ulcers and cancer. It is widely prevalent in developing countries with low socioeconomic status. Since the infection remains asymptomatic in most individuals, efforts for efficient diagnostic markers to identify high risk patients are warranted. In this study, we constructed an expression vector that overexpresses the H. pylori AhpC protein as a glutathione S-transferase fusion protein. We furthermore examined whether this recombinant fusion protein retained immunogenicity and thus would be useful as a diagnostic marker.

Findings: The full-length tsaA gene from H. pylori strain G27, which encodes AhpC, was cloned in plasmid vector pGEX-6P-2 to create the recombinant plasmid vector pGEX-tsaA. The nucleotide sequence of the clone showed $100 \%$ homology with corresponding published sequence of original gene. Over-expression of the target protein GST-AhpC was achieved in E. coli BL21 (DE3) cells by induction with isopropyl-beta-D-thiogalactoside (IPTG). GST-AhpC was extracted and identified using SDS-PAGE as a $52 \mathrm{kDa}$ protein. Western blotting results using commercial antibodies against whole cell $H$. pylori showed that the fusion protein retained immunogenecity.

Conclusion: A recombinant prokaryotic expression system was successfully established with high expression efficiency for target fusion gene $p G E X$-tsaA. The expressed GST-AhpC protein showed immunoreactivity against commercial anti-H. pylori antibodies. This recombinant fusion protein can be developed as a diagnostic marker for screening patients with chronic H. pylori infections.
\end{abstract}

Keywords: Prokaryotic expression system, H. pylori, tsaA, Alkyl hydroperoxide reductase, Recombinant fusion protein, AhpC

\section{Findings \\ Background}

Helicobacter pylori has been recognized as a human gastric pathogen able to colonize in the stomachs of around half of the world's population [1]. Most infected individuals remain asymptomatic, however, the infection may cause acute and chronic gastritis or peptic ulceration, besides being a risk factor for development of gastric adenocarcinoma, mucosa-associated lymphoid tissue (MALT) lymphoma and primary gastric non-Hodgkin's lymphoma [2-5].

\footnotetext{
* Correspondence: khalidadc@yahoo.co.uk

'Department of Microbiology, Quaid-i-Azam University, Islamabad 45320,

Pakistan

${ }^{2}$ Microbiology and Environmental Toxicology Department, University of California Santa Cruz, Santa Cruz, CA 95064, USA

Full list of author information is available at the end of the article
}

H. pylori infection is acquired in early childhood. Like all developing countries, the prevalence of $H$. pylori infection in Pakistan is very high in children. Results of urea breath test in infants from suburbs of Karachi revealed that $80 \%$ were positive for $H$. pylori [6]. H. pylori is able to colonize human stomach for life, if not eradicated. Persistent colonization requires $H$. pylori to avoid damage from by-products of oxygen metabolism and oxidative host responses. $H$. pylori has an impressive array of antioxidant proteins. The bacterium protects itself against such oxidative damage by expressing enzymes like superoxide dismutase SodB [7], catalase KatA [8] and KatA-associated protein KapA [9]. The activities of alkyl hydroperoxide reductase AhpC [10], thiol peroxidases Bcp and Tpx [11] have also been reported to protect $H$. pylori against organic peroxides. NADPH quinone reductase $\mathrm{MdaB}$ [12] and the iron-binding

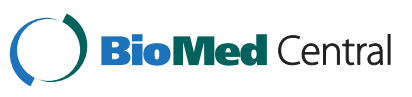

(c) 2012 Mehmood and Hasan; licensee BioMed Central Ltd. This is an Open Access article distributed under the terms of the Creative Commons Attribution License (http://creativecommons.org/licenses/by/2.0), which permits unrestricted use, distribution, and reproduction in any medium, provided the original work is properly cited. 
protein NapA [13] were also found involved in resistance to oxygen stress.

H. pylori AhpC is a thioredoxin (Trx)-dependent $\mathrm{AhpC}$ and a member of the 2-Cys peroxiredoxin family (2-Cys Prxs). AhpC is one of the major proteins for antioxidant defense in $H$. pylori and plays an important role in gastric colonization by the microbe [10]. The tsaA gene was originally annotated as HP1563 in $H$. pylori 26695 [14] and HP1471 in H. pylori 599 [15], however Chalker et al. (2001) annotated the gene as $a h p C$, because this nomenclature is more usual for bacterial alkyl hydroperoxide reductase enzymes [16]. AhpC has been reported in many bacteria, like Escherichia coli and Salmonella typhimurium [17]. H. pylori $\mathrm{AhpC}$ was reported much near to eukaryotic Prxs unlike reductases found in many other bacterial species and indeed, could act like a molecular chaperone similar to Prxs present in yeast and human [18]. Recently, AhpC was found to be consistently expressed in higher amounts in $H$. pylori strains isolated from gastric cancer patients than in patients presenting gastritis only [19]. The 26-kDa protein first reported as an antigenically conserved $H$. pylori species specific protein, is now being predicted to be a useful diagnostic marker for detection of $H$. pylori infection [20]. It was also found associated with a specific antibody response in patients with adenocarcinoma [21].

In the present study, a recombinant expression plasmid containing whole tsaA gene from H. pylori G27 was constructed. The plasmid was cloned in E. coli BL21 cells and recombinant fusion protein was expressed, extracted, identified and analyzed for immunoreactivity with commercial anti $H$. pylori antibodies. The results of this initial work provide a basis for future studies using this fusion protein to develop a specific diagnostic marker for detection of advanced stage diseases like peptic ulcer, gastric cancer and adenocarcinoma due to chronic H. pylori infection in Pakistani population.

\section{Results}

\section{Polymerase chain reaction, cloning and transformation}

The full-length $t s a A$ gene was amplified as described in the methods, digested with restriction enzymes and ligated with $p G E X-6 p-2$ that had been cut with the same enzymes to generate $p G E X$-tsaA. This plasmid places the GST coding sequences N-terminal to the TsaA/AhpC coding sequences and thus should generate rGST-AhpC fusion protein (Figure 1). pGEX-tsaA was used to transform E. coli $\mathrm{DH} 10 \mathrm{~B}$ to ampicillin resistance, and the correct nature of $p G E X-t s a A$ was verified using PCR and DNA sequencing (Figure 2).

\section{Expression of target fusion protein}

We next examined whether $p G E X$-tsaA would overexpress rGST-AhpC. For this experiment we transformed $p G E X$-tsaA into the E. coli strain BL21 (DE3) that encodes a chromosomal T7 RNA Polymerase under the control of a tac promoter. Under IPTG induction, the tac promoter gets activated that drives expression of the rGST-AhpC. We thus added IPTG at concentrations of 0.1 and $1 \mathrm{mmol} / \mathrm{L}$ to mid-log phase cultures of $p G E X$-tsa- BL21 (DE3) grown at $37^{\circ} \mathrm{C}$, and collected whole cell proteins for SDS-PAGE gel analysis. We found that $p G E X-t s a A$ expressed robust amounts of rGST-AhpC that migrated at the expected size of $52 \mathrm{kDa}$ (Figure 3). Further analysis demonstrated that this rGST-AhpC was mainly present as inclusion bodies, based on the observation that the protein was not soluble after cell lysis (Data not shown).

\section{Immunoreactivity of GST-AhpC}

Although it is well known that antibodies against AhpC are generated during $H$. pylori infection, we did not know if such antiserum would recognize a rGST-AhpC fusion protein. We thus tested whether a commercial rabbit antibody that had been generated against whole cell $H$. pylori would recognize our recombinant rGSTAhpC. We obtained robust recognition, confirming that this recombinant protein still displays critical antigenic determinants (Figure 4).

\section{Purification of fusion protein}

Target fusion protein rGST-AhpC was extracted from large volume LB-Amp culture $(1 \mathrm{~L})$ using repeat sonication and washing followed by centrifugation after each step. The samples were checked on 10-12\% SDS-PAGE gel for protein quality. Pellet after third sonication and centrifugation step (Pellet-III) showed best results with a good intense band and little degradation/cleavage products. Pellet-III sample was dialyzed and the supernatant, after dialysis was concentrated to approx. $3 \mathrm{ml}$. Right sized band for fusion protein was observed in case of both dialyzed and concentrated protein samples with no apparent degradation product as compared to pelletIII sample without dialysis and concentration (Figure 5).

\section{Discussion}

The study of virulence factors and important antigens of $H$. pylori is important to understand bacterial mechanisms involved in persistent colonization and inflammation. Prokaryotic expression systems for several important $H$. pylori virulence factors have been successfully constructed and recombinant fusion proteins or their purified proteins used in seroprevalence studies or screened as $H$. pylori vaccine candidates [22-24], however, little attention has been paid towards protein products of housekeeping genes like $t s a A(a h p C)$.

Wang et al. (2005) reported that mutant H. pylori strains defective in $\mathrm{AhpC}$ were more sensitive to oxidative stress conditions compared to wild-type cells [25]. Also, 


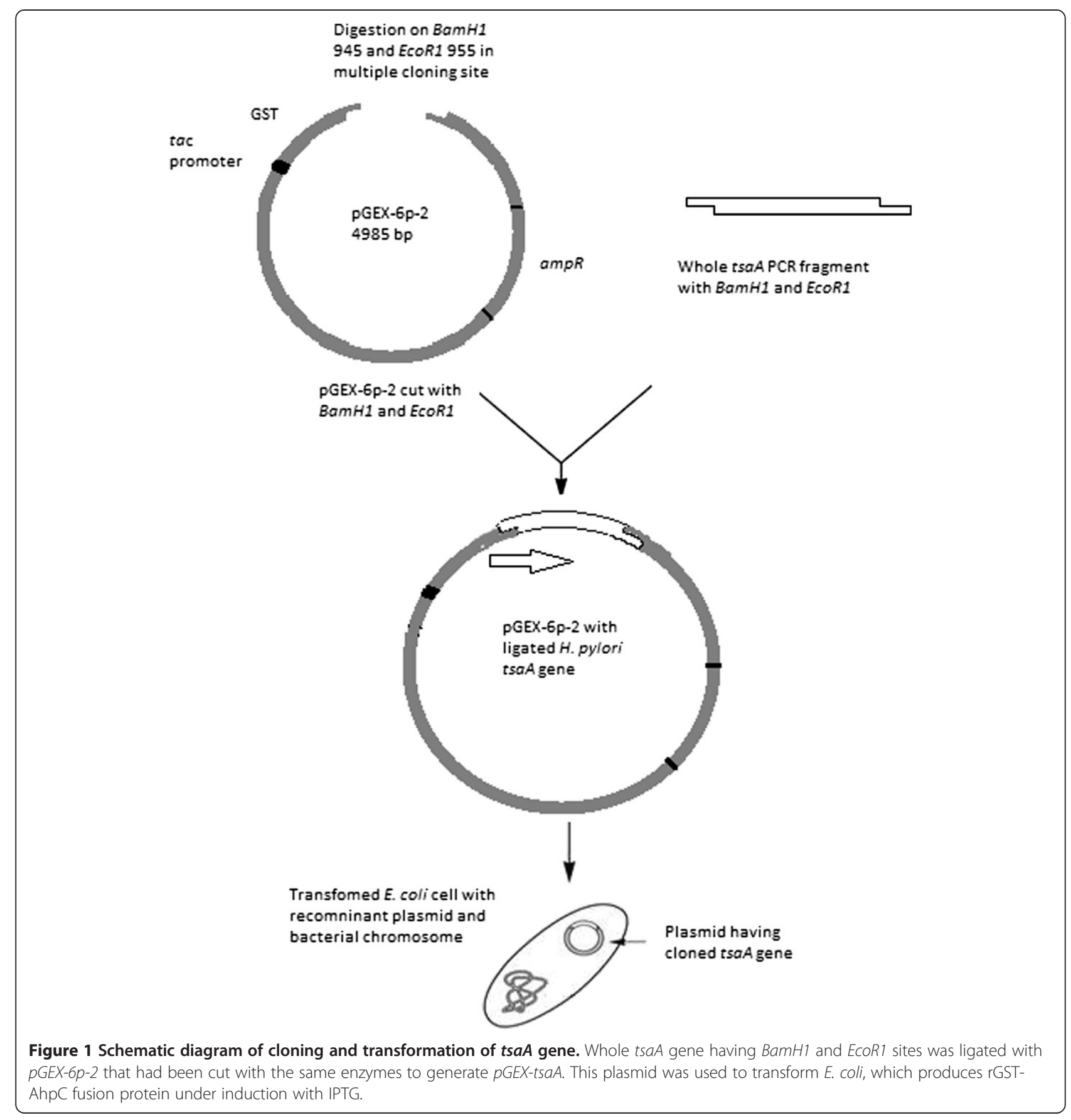

Olczak et al., (2003) reported that $a h p C / t s a A$ mutant strains were unable to colonize mouse stomach [26]. An important feature of $\mathrm{AhpC}$ is that it seems to promote the activity of other proteins. Specifically, loss of AhpC resulted in partial inactivation of catalase, suggesting that $\mathrm{AhpC}$ is required for proper catalase activity [27].

At least two studies reported that antibodies against AhpC were found only in $H$. pylori infections that resulted in disease. Wang et al., 2004 found antibodies against AhpC in sera of peptic ulcer, cancer and adenocarcinoma patients infected with $H$. pylori [21]. In a recent report, Haung et al., 2011 examined protein expression levels of AhpC in $H$. pylori from different clinical manifestations and observed 5-fold increase in AhpC protein expression in strains isolated from gastric cancer patients than those from gastritis [19]. This describes the potential of AhpC as an efficient biomarker to identify and risk patient population presenting different stages of dseases associated with chronic $H$. pylori infections. 


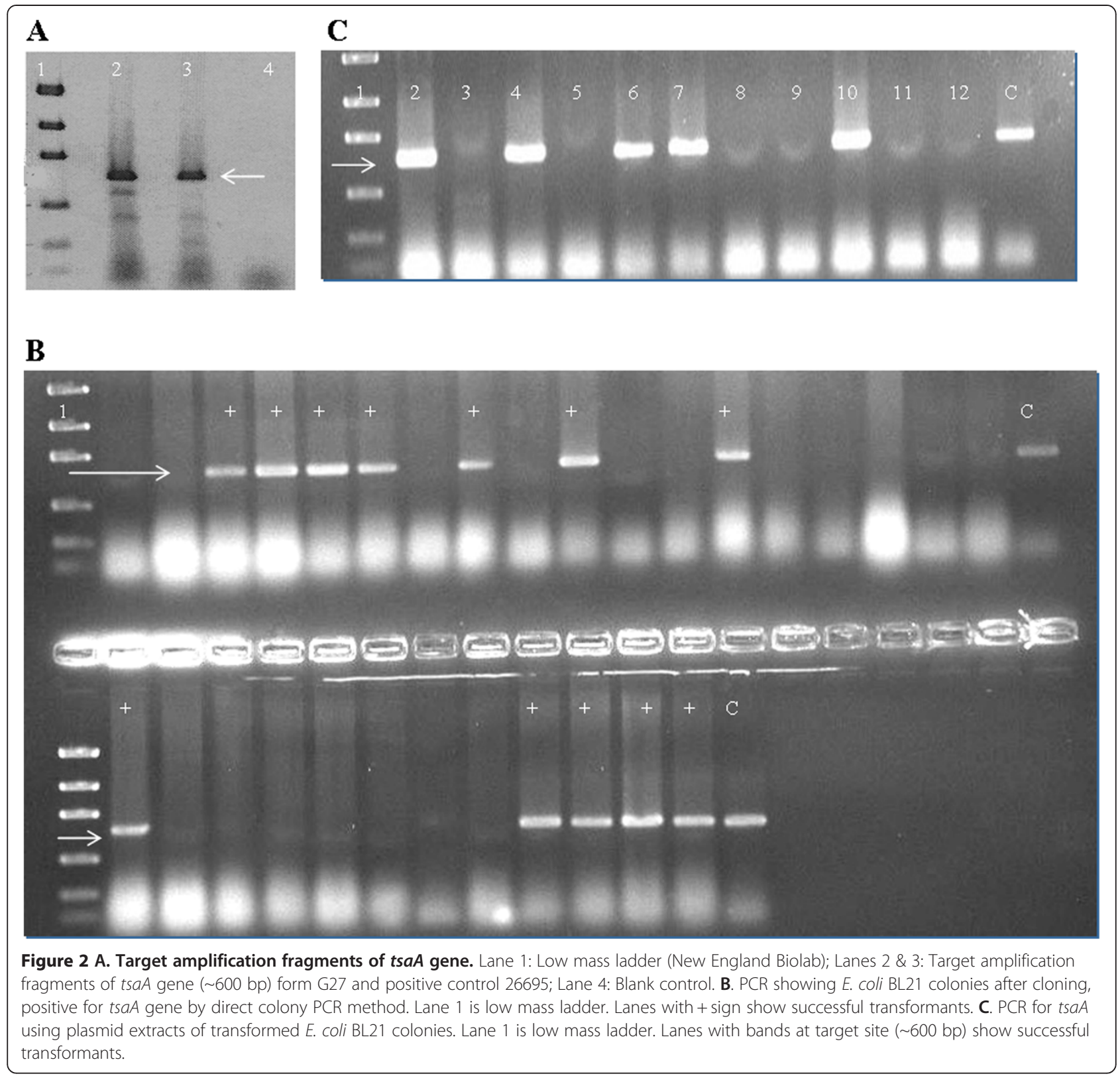

Another important $H$. pylori antigen associated with disease is CagA. Patients infected with $\operatorname{cagA}{ }^{+} H$. pylori have higher risk of developing gastric cancers than those infected with cagA $A^{-}$strains $[28,29]$. Various studies have reported that 60 to $70 \%$ of $H$. pylori strains isolated from European and North American populations carried the cagA gene [30-32], whereas over $90 \%$ of the isolates from Asia-Pacific populations were found to be $\operatorname{cag} A^{+}$[33-35]. The fact that nearly all strains of $H$. pylori from countries like Taiwan and China as well as a high proportion in western countries are cagA positive makes it difficult to use cagA only as a marker for screening high-risk patients in these populations.
The $t s a A$ gene from $H$ pylori strain G27, cloned in this study, showed $100 \%$ nucleotide homology with published corresponding sequences. In the present study, SDSPAGE demonstrated that the constructed expression systems $p G E X-6 p-2-t s a A-B L 21$ (DE3) efficiently produced the target recombinant GST fusion protein, however mainly presented in the form of inclusion body. However, we successfully obtained free of inclusion body fusion protein using repeat sonication and centrifugation protocol which can be extended to subsequent refolding and cleavage from GST tag. The commercial rabbit antiserum against the whole cell of $H$. pylori recognized and combined with rGST-AhpC as confirmed by Western 


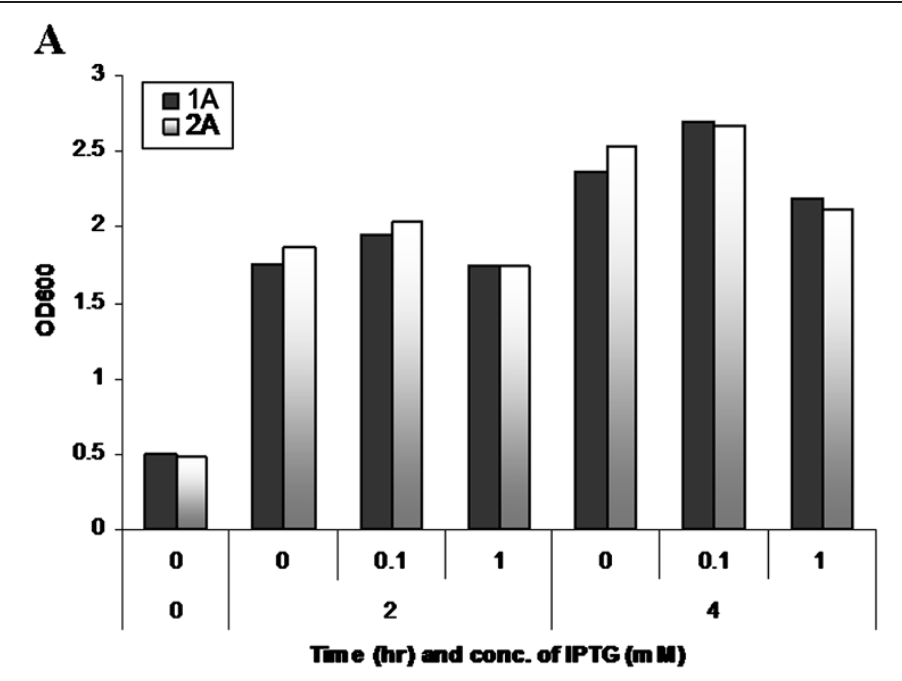

B

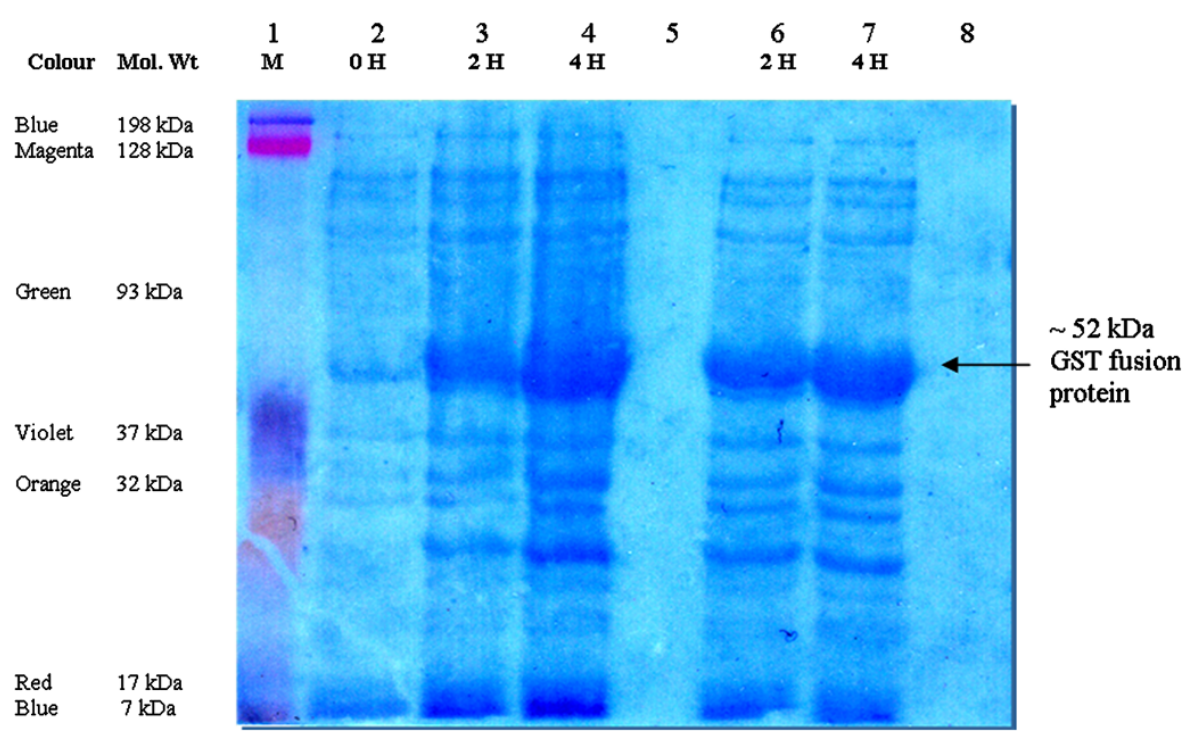

Figure $3 \mathrm{~A}$. Growth curves showing $\mathrm{OD}_{600}$ of $E$. coli BL21 cells for induction of AhpC with 0.1 and $1 \mathrm{mM}$ IPTG at 0,2 and 4 hours of growth. $1 \mathrm{~A}$ and $2 \mathrm{~A}$ are duplicate samples. B. SDS-PAGE showing $\sim 52 \mathrm{kDa}$ target recombinant fusion protein (rGST-AhpC). Lane 1: Kaleidoscope colour marker (BioRad); Lanes 2-4 Protein samples induced with $0.1 \mathrm{mM} \mathrm{IPTG}$ at 0, 2 and 4 hours respectively; Lanes 6-7: Protein samples induced with 1 mM IPTG; Lanes 5 \& 8: Blank controls.

blot, indicating that the fusion protein had high immunoreactivity. However, we could not explain presence of lower intensity bands other than that of the right sized band, both in SDS-PAGE (Figure 3B) and their subsequent recognition in Western Blot (Figure 4). Perhaps these are E. coli BL21 (DE3) proteins which crossreacted with the commercial rabbit antiserum against the whole cell of $H$. pylori. Several other approaches have been used for construction and use of prokaryotic expression system for potential $H$. pylori vaccine candidates like flaA, flab, ureB and cagA by other groups [22-24].
Limitations of present study include use of GST fusion protein itself and not its cleaved purified product, and not testing the sera of potential patient groups to demonstrate the effectiveness of this approach due to some constraints.

\section{Conclusions}

We have successfully constructed an efficient expression system for $a h p C$, an important gene of $H$. pylori in $p G E X-6 p-2$. This construct was successfully transformed in E. coli BL21 (DE3) that gave a recombinant fusion protein (rGST-AhpC), mainly as inclusion body. 


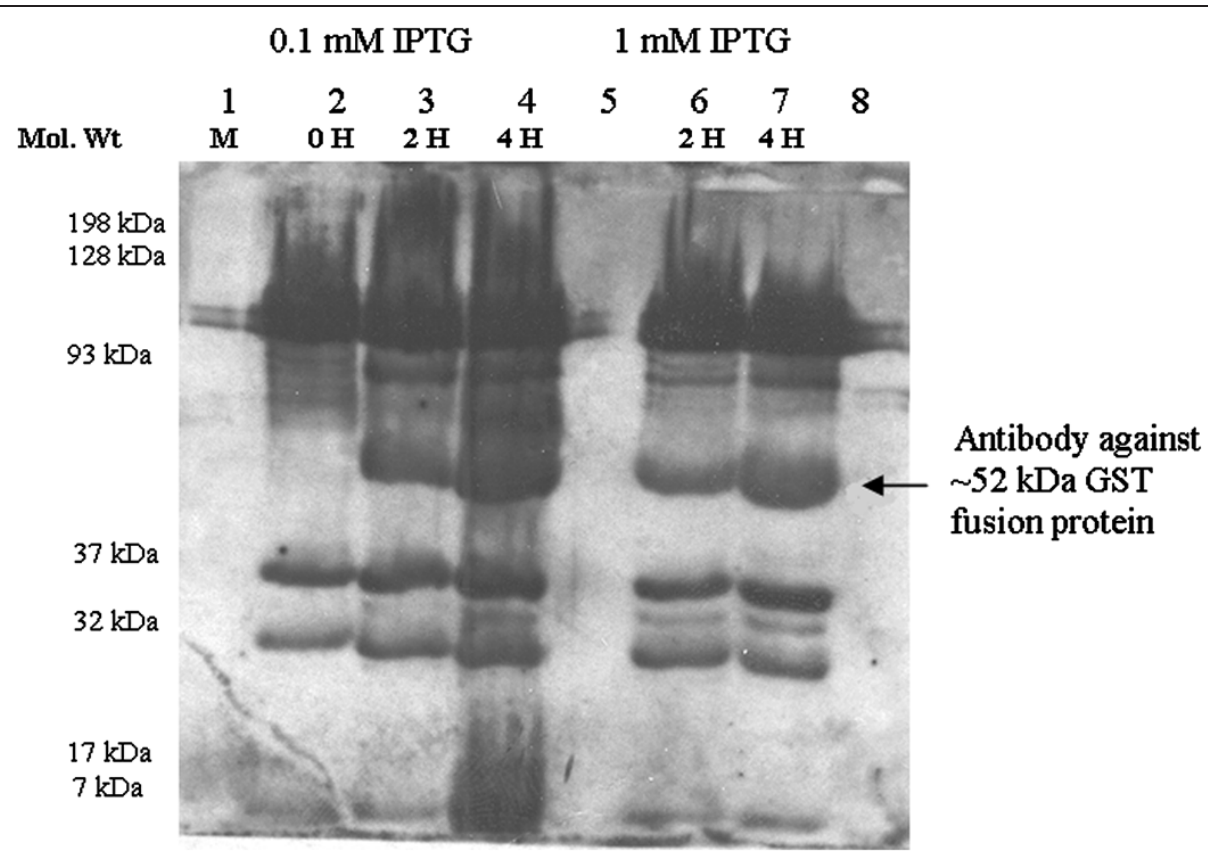

Figure 4 Western Blot showing detection of target $\sim 52$ kDa GST fusion protein by Rabbit anti $H$. pylori antibodies as primary antibody. Lane 1: Kaleidoscope colour marker; Lanes 2-4: Protein samples induced in E. coli BL21 cells with $0.1 \mathrm{mM}$ IPTG at 0, 2 and 4 hours respectively; Lanes 6-7: Protein samples induced with 1 mM IPTG; Lanes 5 \& 8: Blank controls.

Immunoreactivity against rGST-AhpC was tested against commercial anti-H. pylori antibodies raised in rabbit serum. The fusion protein was then processed to get free from inclusion body. This recombinant fusion protein can serve as a potential diagnostic marker for screening advanced clinical manifestations due to chronic $H$. pylori infections. Such strategies are need of the time to identify high risk patients keeping in view the genetic diversity of $H$. pylori regarding a well accepted biomarker CagA across the globe.

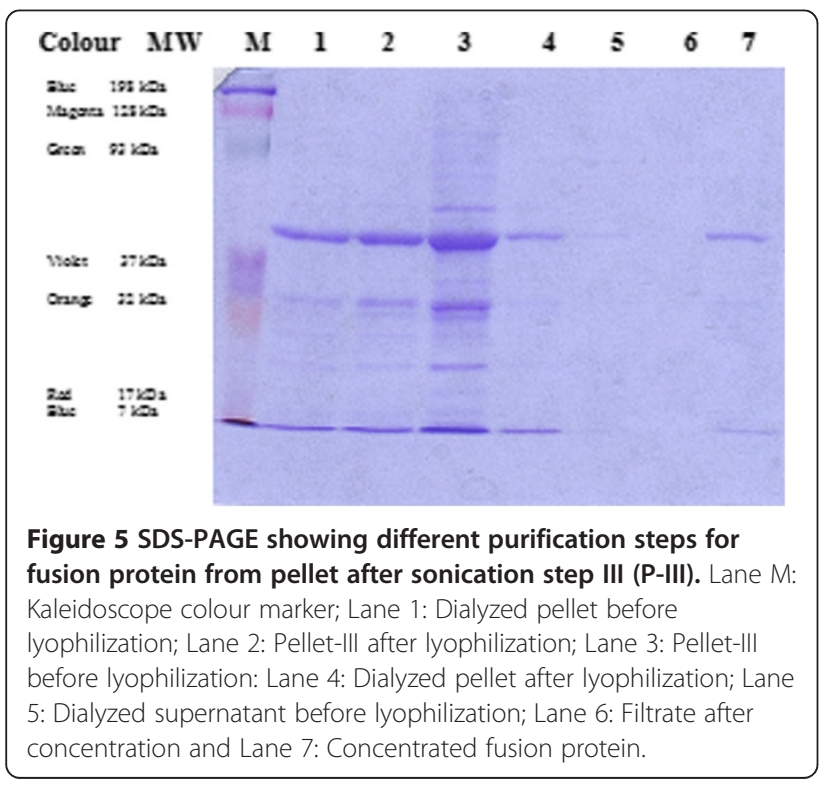

\section{Methods}

\section{Bacterial strains}

Bacterial strains used are given in Table 1. E. coli strain DH10B was used for cloning and BL21 (DE3) used for protein expression.

\section{Growth media and chemicals}

For solid-medium culture, H. pylori was grown on Columbia blood agar (Becton Dickinson) plates with 5\% defibrinated horse blood (Hemostat Labs, Davis, CA), $5 \mu \mathrm{g}$ of trimethoprim $/ \mathrm{ml}, 8 \mu \mathrm{g}$ of amphotericin $\mathrm{B} / \mathrm{ml}$, $10 \mu \mathrm{g}$ of vancomycin $/ \mathrm{ml}, 50 \mu \mathrm{g}$ of cycloheximide $/ \mathrm{ml}$, $5 \mu \mathrm{g}$ of cefsulodin/ml, $2.5 \mathrm{U}$ of polymyxin $\mathrm{B} / \mathrm{ml}, 0.2 \%$ (wt/vol) $\beta$-cyclodextrin (Sigma) (CHBA) at $37^{\circ} \mathrm{C}$ under conditions of $10 \% \mathrm{O} 2,10 \% \mathrm{CO}_{2}$ and $80 \% \mathrm{~N} 2$. All antibiotics were from Sigma or ISC Bioexpress. E. coli strains were grown on LB Agar or broth with Ampicillin and incubated on $37^{\circ} \mathrm{C}$ for overnight (LB-Amp). For long-term storage of $H$. pylori strains, 3-5 day growth of H. pylori was transferred to brucella broth having $10 \%$ FBS (BB10), 1\% $\beta$-cyclodextrin, 5\% dimethyl sulfoxide and $25 \%$ glycerol. The cells were frozen at $-70^{\circ} \mathrm{C}$ after pipetting and vortexing.

\section{DNA extraction}

Genomic DNA from 2-3 days culture of $H$. pylori strain G27 was extracted using Wizard genomic kit (Promega) according to manufacturer's instructions. 
Table 1 Strains and plasmid used in the study

\begin{tabular}{lll}
\hline Strain & Genotype/description & Source \\
\hline E. coli & & \\
\hline DH10B & Cloning strain & Promega \\
\hline BL21 (DE3) & E. coli B F- dcm ompT hsdS (rB-mB-) gal $\lambda(\mathrm{DE} 3)[\mathrm{pLysS}$ Camr] & Promega \\
\hline $\boldsymbol{H .}$ pylori & & \\
\hline G27 & Wild type & Nina R. Salama, University of Washington, Seattle, WA \\
\hline 26695 & Wild type & Karen M. Ottemann, UC Santa Cruz, CA \\
\hline Plasmids & & \\
\hline pGEX-6p-2 & GST fusion plasmid & Novagen \\
\hline
\end{tabular}

\section{Primers}

Primers were designed from genome sequence of $H$. pylori 26695 (HP1563) to amplify the full-length sequence of HP1563/tsaA using the U.C. Santa Cruz archeal genome browser (http://archaea.ucsc.edu). Forward primer 5' -CTCTGGATCCATGTTAGTTACAAAACTTGCC-3' having restriction endonuclease site of $\mathrm{BamH} 1$ and reverse primer $5^{\prime}$-CTCTGAATTCTTAAAGCTTAATGGAATTTTC-3' with EcoR1 site were used to amplify full length $t s a A$ gene from $H$. pylori G27 genomic DNA. Primers were synthesized by Eurofins MWG Operon, (Huntsville, USA).

\section{Polymerase chain reaction}

PCR reaction mixture contained 100 ng of $H$. pylori G27 genomic DNA, $2.5 \mu \mathrm{l}$ of dNTPs, $2.5 \mu \mathrm{l}$ of $30 \mathrm{mM} \mathrm{MgCl}_{2}$ PCR buffer, $200 \mathrm{ng}$ of each primer and $1 \mu \mathrm{l}$ of Taq polymerase. Final volume was made to $25 \mu \mathrm{l}$ with sterile water. Genomic DNA of H. pylori 26695 in same concentration was used as positive control. PCR conditions were: Initial melting at $94^{\circ} \mathrm{C}$ for 3 minutes, then 30 cycles of repeat melting at $94^{\circ} \mathrm{C}$ for $40 \mathrm{sec}$, annealing at $52^{\circ} \mathrm{C}$ for 40 seconds and initial extension at $72^{\circ} \mathrm{C}$ for 30 seconds, then final extension at $72^{\circ} \mathrm{C}$ for 3 minutes and storage at $4^{\circ} \mathrm{C}$ until run on the gel. The results of PCR were observed under UV light after electrophoresis on $1.5 \%$ agarose gel stained with ethidium bromide. The expected size of $t s a A$ amplification fragment was $\sim 600 \mathrm{bp}$.

\section{Sequencing}

Sequencing of PCR products was done by the DNA sequencing facility, UC Berkeley, CA. A sample containing $100 \mathrm{ng}$ gel purified DNA and $0.8 \mathrm{pg}$ of forward or reverse primer was adjusted to a total volume of $\sim 13 \mu \mathrm{l}$ in $\mathrm{dH}_{2} \mathrm{O}$. Sequences obtained were subjected to nucleotide BLAST feature of National Center for Biotechnology Information (NCBI) website (http://blast.ncbi.nlm.nih.gov/ Blast.cgi) for homology analyses with published tsaA sequence of G27.

\section{Cloning of tsaA gene into plasmid vector}

Gel purified $t s a A$ whole gene was cloned into plasmid vector $p G E X-6 p-2$. Both the $t s a A$ PCR product and plasmid were digested with restriction endonucleases BamHI and EcoRI (New England Biolabs) at $37^{\circ} \mathrm{C}$ overnight. Digested DNA and plasmid were gel purified and concentration was determined by Nanodrop. The plasmid sample was treated with Shrimp alkaline phosphatase (New England BioLabs). Ligation was done with 0.5 $\mu \mathrm{l}$ T4 ligase enzyme (New England Biolabs) by incubating the ligation mix at $16^{\circ} \mathrm{C}$ for overnight. This plasmid was transformed into E. coli DH10B using electroporation; ampicillin-resistant colonies were screened using direct colony PCR using the original tsaA primers. One colony containing the correct plasmid was used to purify plasmid for sequencing.

\section{Expression and identification of target recombinant protein}

pGEX-Recombinant plasmid was transformed through electroporation into E. coli BL21 (DE3) (Promega). One BL21 (DE3) colony of successful transformant containing $p G E X-t s a A$ was cultured in LB-Amp broth at $37^{\circ} \mathrm{C}$ until $\mathrm{OD}_{600}$ of 0.5 , after which IPTG was added at concentrations of 0.1 and 1.0 and $\mathrm{mmol} / \mathrm{L}$. Cultures were incubated for the times indicated in Figure 3A. Cells were then collected by centrifugation at $6000 \mathrm{X} \mathrm{g}$ force. The bacterial pellet was resuspended in 200-300 $\mu \mathrm{l}$ of 2x Laemmli sample buffer (1.52 g Tris-Base, 2 g SDS,

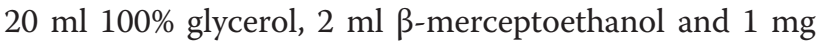
bromophenol blue in $\mathrm{dH}_{2} \mathrm{O}$ to make $100 \mathrm{ml}$ ), and resuspended pellets were boiled for 5 minutes on water bath for denaturing proteins. SDS-PAGE (10\%) was used to measure the molecular mass and output of the target recombinant fusion protein (rGST-AhpC).

\section{Immunoreactivity of recombinant fusion protein}

Immunoreactivity of the fusion protein was then determined. Briefly, PVDF membrane (BioRad) cut to the size of the gel was pre-wet in 100\% Methanol. Gel, sponge pads, 4 pieces of Whatman filter paper and $\mathrm{MeOH}$ - 
soaked membrane were soaked in the transfer buffer (1X SDS-PAGE Running Buffer, 20\% MeOH) for 10 minutes. The cassettes were closed and placed in the module and contents of the gel transferred to membrane at $250 \mathrm{~mA}$ for 75 minutes. The commercial rabbit antiserum against whole-cell $H$ pylori (Santa Cruz Biotech. USA) in 1:1000 dilution and HRP-labeling sheep antiserum against rabbit IgG in 1:7500 dilution (Santa Cruz Biotech, USA) were used as the first and second antibodies to determine the immunoreactivity of rGST-AhpC by Western blotting, respectively. Results were visualized using luminol and Biomax Light Film (Kodak).

\section{Isolation of fusion protein from inclusion bodies}

The fusion protein was isolated from inclusion bodies by using an online protocol (http://www.its.caltech.edu/ bjorker/Protocols) with some modifications. Briefly, culture from single colony of successful transformant grown in $1 \mathrm{~L}$ LB-Amp broth was centrifuged (Sorvall RC5C Plus, Thermo Fischer Scientific, Rockford, USA) at $7000 \mathrm{X} g$ for 20 minutes at $4^{\circ} \mathrm{C}$. Resultant supernatant was carefully decanted and pellet was resuspended in $13 \mathrm{ml}$ of solution buffer (50 mM Tris- $\mathrm{HCl}, 25 \%$ sucrose, $1 \mathrm{mM}$ NaEDTA, 0.1\% Sodium azide and $10 \mathrm{mM}$ DTT) on ice and sonicated (Sonic Dismembrator, Fischer Scientific, Rockford, USA) at 50\% amplitude for 4-5 times on ice. Then $100 \mu$ l Lysozyme, $250 \mu \mathrm{l}$ DNase I and $50 \mu \mathrm{l}$ $\mathrm{MgCl}_{2}$ were mixed with $12.5 \mathrm{ml}$ of lysis buffer $(50 \mathrm{mM}$ Tris- $\mathrm{HCl}, 1 \%$ Triton X-100, $1 \% \mathrm{Na}$ deoxycholate, $100 \mathrm{mM} \mathrm{NaCl}, 0.1 \%$ Sodium azide and $10 \mathrm{mM}$ DTT) and sample was incubated for 45 minutes at room temperature. In next step, $350 \mu \mathrm{l}$ of NaEDTA was added to the sample and freezed in liquid nitrogen. The sample was then thawed at $37^{\circ} \mathrm{C}$ for 30 minutes. $200 \mu \mathrm{l} \mathrm{MgCl}_{2}$ solution was added to the solution and placed at room temperature for an hour. Then $350 \mathrm{ml}$ NaEDTA was added again to the solution and placed on ice. This solution was centrifuged at $11000 \mathrm{X} g$ at $4^{\circ} \mathrm{C}$ for 20 minutes and supernatant was discarded in a tube. The pellet was washed with $10 \mathrm{ml}$ washing buffer $(50 \mathrm{mM}$ Tris- $\mathrm{HCl}$, 0.5\% Triton X-100, $100 \mathrm{mM} \mathrm{NaCl,} 1 \mathrm{mM}$ NaEDTA, $0.1 \%$ Sodium azide and $1 \mathrm{mM} \mathrm{DTT}$ ) and sonicated on ice. Solution was spun again at $11000 \mathrm{X} g$ for 20 minutes at $4^{\circ} \mathrm{C}$ and supernatant was discarded in a tube. Pellet was again resuspended in $10 \mathrm{ml}$ washing buffer but this time without Triton X-100 and sonicated. The same procedure was repeated for third time. Samples from both supernatant and pellet after each centrifugation step were retained for checking protein quality. In the last step, pellet was dissolved in $5 \mathrm{ml}$ of $8 \mathrm{M}$ Guanidinium solution ( $\mathrm{pH} 8.0)$ in the presence of $4 \mathrm{mM}$ DTT and shaken at room temperature till complete dissolution. The dissolved sample was stored at $-80^{\circ} \mathrm{C}$.

\section{Dialysis and concentration}

Solution was diluted to $50 \mathrm{ml}$ with minimal protein buffer $(150 \mathrm{mM} \mathrm{NaCl}$ and $50 \mathrm{mM}$ Tris- $\mathrm{HCl}$ at $\mathrm{pH} 8.0)$ and dialyzed against $1 \mathrm{~L}$ of MPB using SnakeSkin dialysis tubing (Thermo Fischer Scientific, Rockford, USA) with gentle shaking at $4{ }^{\circ} \mathrm{C}$. After 2 hours of shaking, the buffer was changed and then dialyzed overnight. Solution was pelleted at $3000 \mathrm{X} \mathrm{g}$ for 20 minutes at $4{ }^{\circ} \mathrm{C}$. The resultant supernatant was concentrated to about $3 \mathrm{ml}$ volume using Amicon Ultra-15 concentrator (Millipore, USA) following manufacturer's instructions. Both concentrated and dialyzed pellets were analyzed for proteins on SDS-PAGE. Both the pellet and concentrate were lyophilized (FreeZone 2.5 Freeze Dry Systems, Labconco, Kansas, USA) for long term storage and further use.

\section{Competing interests}

The authors declare no competing interests.

\section{Authors' contributions}

KM conceived the study, carried out the experimental work and prepared the initial draft of the manuscript. FH helped in result interpretation and preparation of final draft. All authors read and approved the final manuscript.

\section{Acknowledgment}

We are thankful to Pakistan Higher Education Commission (HEC) for funding this research work, and Karen M. Ottemann (UC Santa Cruz, CA) for providing lab space and technical advice.

\section{Author details}

${ }^{1}$ Department of Microbiology, Quaid-i-Azam University, Islamabad 45320, Pakistan. ${ }^{2}$ Microbiology and Environmental Toxicology Department, University of California Santa Cruz, Santa Cruz, CA 95064, USA. ${ }^{3}$ Department of Pharmacy, Hazara University, Havelian, Abbottabad, Pakistan.

Received: 29 February 2012 Accepted: 21 June 2012

Published: 25 June 2012

\section{References}

1. Brown LM: Helicobacter pylori: epidemiology and routes of transmission. Epidemiol Rev 2000, 22(2):283-297.

2. Nakamura S, Matsumoto T, Suekane H, Takeshita M, Hizawa K, Kawasaki M, Yao T, Tsuneyoshi M, lida M, Fujishima M: Predictive value of endoscopic ultrasonography for regression of gastric low grade and high grade MALT lymphomas after eradication of Helicobacter pylori. Gut 2001, 48(4):454-460.

3. Uemura N, Okamoto S, Yamamoto S, Matsumura N, Yamaguchi S, Yamakido M, Taniyama K, Sasaki N, Schlemper RJ: Helicobacter pylori infection and the development of gastric cancer. N Engl J Med 2001, 345(11):784-789.

4. Morgner A, Bayerdorffer E, Neubauer A, Stolte M: Gastric MALT lymphoma and its relationship to Helicobacter pylori infection: management and pathogenesis of the disease. Microsc Res Tech 2000, 48(6):349-356.

5. Kate V, Ananthakrishnan N, Badrinath S: Effect of Helicobacter pylori eradication on the ulcer recurrence rate after simple closure of perforated duodenal ulcer: retrospective and prospective randomized controlled studies. Br J Surg 2001, 88(8):1054-1058.

6. Nizami SQ, Bhutta ZA, Weaver L, Preston T: Helicobacter pylori colonization in infants in a peri-urban community in Karachi, Pakistan. J Pediatr Gastroenterol Nutr 2005, 41(2):191-194.

7. Seyler RW Jr, Olson JW, Maier RJ: Superoxide dismutase-deficient mutants of Helicobacter pylori are hypersensitive to oxidative stress and defective in host colonization. Infect Immun 2001, 69(6):4034-4040.

8. Basu M, Czinn SJ, Blanchard TG: Absence of catalase reduces long-term survival of Helicobacter pylori in macrophage phagosomes. Helicobacter 2004, 9(3):211-216

9. Harris AG, Hinds FE, Beckhouse AG, Kolesnikow T, Hazell SL: Resistance to hydrogen peroxide in Helicobacter pylori: role of catalase (KatA) and Fur, 
and functional analysis of a novel gene product designated 'KatAassociated protein', KapA (HP0874). Microbiology 2002, 148(Pt 12):3813-3825.

10. Baker LM, Raudonikiene A, Hoffman PS, Poole LB: Essential thioredoxindependent peroxiredoxin system from Helicobacter pylori: genetic and kinetic characterization. J Bacterio/ 2001, 183(6):1961-1973.

11. Wang G, Olczak AA, Walton JP, Maier RJ: Contribution of the Helicobacter pylori thiol peroxidase bacterioferritin comigratory protein to oxidative stress resistance and host colonization. Infect Immun 2005, 73(1):378-384.

12. Wang $G$, Maier RJ: An NADPH quinone reductase of Helicobacter pylori plays an important role in oxidative stress resistance and host colonization. Infect Immun 2004, 72(3):1391-1396.

13. Evans DJ Jr, Evans DG, Takemura T, Nakano H, Lampert HC, Graham DY, Granger DN, Kvietys PR: Characterization of a Helicobacter pylori neutrophil-activating protein. Infect Immun 1995, 63(6):2213-2220.

14. Tomb JF, White O, Kerlavage AR, Clayton RA, Sutton GG, Fleischmann RD, Ketchum KA, Klenk HP, Gill S, Dougherty BA, et al: The complete genome sequence of the gastric pathogen Helicobacter pylori. Nature 1997, 388(6642):539-547.

15. Alm RA, Ling LS, Moir DT, King BL, Brown ED, Doig PC, Smith DR, Noonan B, Guild BC, deJonge BL, et al: Genomic-sequence comparison of two unrelated isolates of the human gastric pathogen Helicobacter pylori. Nature 1999, 397(6715):176-180.

16. Chalker AF, Minehart HW, Hughes NJ, Koretke KK, Lonetto MA, Brinkman KK, Warren PV, Lupas A, Stanhope MJ, Brown JR, et al: Systematic identification of selective essential genes in Helicobacter pylori by genome prioritization and allelic replacement mutagenesis. J Bacteriol 2001, 183(4):1259-1268.

17. Storz G, Jacobson FS, Tartaglia LA, Morgan RW, Silveira LA, Ames BN: An alkyl hydroperoxide reductase induced by oxidative stress in Salmonella typhimurium and Escherichia coli: genetic characterization and cloning of ahp. J Bacteriol 1989, 171(4):2049-2055.

18. Chuang MH, Wu MS, Lo WL, Lin JT, Wong CH, Chiou SH: The antioxidant protein alkylhydroperoxide reductase of Helicobacter pylori switches from a peroxide reductase to a molecular chaperone function. Proc Nat Acad Sci U S A 2006, 103(8):2552-2557.

19. Huang CH, Chuang MH, Lo WL, Wu MS, Wu YH, Wu DC, Chiou SH Alkylhydroperoxide reductase of Helicobacter pylori as a biomarker for gastric patients with different pathological manifestations. Biochimie 2011, 93(7):1115-1123.

20. OToole PW, Logan SM, Kostrzynska M, Wadstrom T, Trust TJ: Isolation and biochemical and molecular analyses of a species-specific protein antigen from the gastric pathogen Helicobacter pylori. J Bacteriol 1991, 173(2):505-513.

21. Wang JT, Chang CS, Lee CZ, Yang JC, Lin JT, Wang TH: Antibody to a Helicobacter pylori species specific antigen in patients with adenocarcinoma of the stomach. Biochem Biophys Res Commun 1998, 244(2):360-363.

22. Yan J, Liang SH, Mao YF, Li LW, Li SP: Construction of expression systems for flaA and flaB genes of Helicobacter pylori and determination of immunoreactivity and antigenicity of recombinant proteins. World $J$ Gastroenterol 2003, 9(10):2240-2250

23. Yan J, Wang Y, Shao SH, Mao YF, Li HW, Luo YH: Construction of prokaryotic expression system of ItB-ureB fusion gene and identification of the recombinant protein immunity and adjuvanticity. World J Gastroenterol 2004, 10(18):2675-2679.

24. Yan J, Wang Y, Shao SH, Mao YF, Li HW, Luo YH: Construction of prokaryotic expression system of 2 148-bp fragment from cagA gene and detection of cagA gene, CagA protein in Helicobacter pylori isolates and its antibody in sera of patients. World J Gastroenterol 2004, 10(8):1183-1190.

25. Wang G, Conover RC, Olczak AA, Alamuri P, Johnson MK, Maier RJ Oxidative stress defense mechanisms to counter iron-promoted DNA damage in Helicobacter pylori. Free Radic Res 2005, 39(11):1183-1191.

26. Olczak AA, Seyler RW Jr, Olson JW, Maier RJ: Association of Helicobacter pylori antioxidant activities with host colonization proficiency. Infect Immun 2003, 71(1):580-583.

27. Wang G, Conover RC, Benoit S, Olczak AA, Olson JW, Johnson MK, Maier RJ: Role of a bacterial organic hydroperoxide detoxification system in preventing catalase inactivation. J Biol Chem 2004, 279(50):51908-51914.

28. Blaser MJ, Perez-Perez GI, Kleanthous H, Cover TL, Peek RM, Chyou PH, Stemmermann GN, Nomura A: Infection with Helicobacter pylori strains possessing cag $\mathrm{A}$ is associated with an increased risk of developing adenocarcinoma of the stomach. Cancer Res 1995, 55(10):2111-2115.

29. Parsonnet J, Friedman GD, Orentreich N, Vogelman H: Risk for gastric cancer in people with CagA positive or CagA negative Helicobacter pylori infection. Gut 1997, 40(3):297-301.

30. Tummuru MK, Cover TL, Blaser MJ: Cloning and expression of a highmolecular-mass major antigen of Helicobacter pylori: evidence of linkage to cytotoxin production. Infect Immun 1993, 61(5):1799-1809.

31. Covacci A, Censini S, Bugnoli M, Petracca R, Burroni D, Macchia G, Massone A, Papini E, Xiang Z, Figura N, et al: Molecular characterization of the 128-kDa immunodominant antigen of Helicobacter pylori associated with cytotoxicity and duodenal ulcer. Proc Natl Acad Sci U S A 1993, 90(12):5791-5795.

32. Figueiredo C, Van Doorn $\sqcup$, Nogueira C, Soares JM, Pinho C, Figueira P, Quint WG, Carneiro F: Helicobacter pylori genotypes are associated with clinical outcome in Portuguese patients and show a high prevalence of infections with multiple strains. Scand J Gastroenterol 2001, 36(2):128-135.

33. Ito $Y$, Azuma T, Ito $S$, Miyaji $H$, Hirai M, Yamazaki $Y$, Sato F, Kato T, Kohli Y, Kuriyama M: Analysis and typing of the vacA gene from cagA-positive strains of Helicobacter pylori isolated in Japan. J Clin Microbiol 1997, 35(7):1710-1714.

34. Park SM, Park J, Kim JG, Yoo BC: Relevance of vacA genotypes of Helicobacter pylori to cagA status and its clinical outcome. Korean $J$ Intern Med 2001, 16(1):8-13.

35. Yang H, Wu SV, Pichuantes S, Song M, Wang J, Zhou D, Xu Z, Quan S, Polito A, Walsh JH: High prevalence of cagA-positive strains in Helicobacter pylori-infected, healthy, young Chinese adults. J Gastroenterol Hepatol 1999, 14(5):476-480.

doi:10.1186/1756-0500-5-328

Cite this article as: Mehmood and Hasan: Construction and use of a prokaryotic expression system for Helicobacter pylori AhpC. BMC Research Notes 2012 5:328.

\section{Submit your next manuscript to BioMed Central and take full advantage of:}

- Convenient online submission

- Thorough peer review

- No space constraints or color figure charges

- Immediate publication on acceptance

- Inclusion in PubMed, CAS, Scopus and Google Scholar

- Research which is freely available for redistribution 